\title{
Kompetensi Kolokasi dan Keterampilan Menulis Mahasiswa Jurusan Bahasa Inggris Politeknik Negeri Bandung
}

\author{
Saudin \\ Jurusan Bahasa Inggris, Politeknik Negeri Bandung, Bandung, Indonesia \\ Email: saudin@polban.ac.id
}

\begin{abstract}
RINGKASAN
Kolokasi merupakan fitur bahasa yang menjadi ciri utama kualitas berbahasa seorang pemelajar. Penguasaan atau kompetensinya menjadi bagian penting dari kompetensi komunikasi penutur asli (Bazzaz \& Samad, 2011). Penelitian kolokasi yang membahas pengetahuan kolokasi secara lebih spesifik dengan memilahnya ke dalam kompetensi produktif dan reseptif masih sedikit (Henriksen, 2013). Penelitian ini bertujuan untuk mengungkap tingkat kompetensi produktif dan reseptif kolokasi tipe $v+n$ dan $a d j+n$ subjek penelitian, 49 mahasiswa semester empat Jurusan Bahasa Inggris, dan hubungan antara kompetensi kolokasi produktif dan reseptif mereka dengan keterampilan menulis. Untuk tujuan tersebut, penelitian kualitatif ini mengaplikasikan tiga instrumen, blank-filling test of English collocations untuk memperoleh data mengenai tingkat kompetensi kolokasi produktif, multiple-choice test of English collocations untuk mengetahui tingkat kompetensi kolokasi reseptif, dan writing test untuk mengungkap tingkat keterampilan menulis subjek. Analisis terhadap instrumen menghasilkan temuan bahwa nilai kompetensi produktif kolokasi $v+n$ dan $a d j+n$ cukup baik tapi lebih rendah daripada nilai kompetensi reseptif dua tipe kolokasi tersebut. Analisis juga menunjukkan subjek meraih keterampilan menulis level 4 (cukup baik) tapi dengan beberapa catatan. Analisis lebih jauh menunjukkan kompetensi kolokasi produktif memiliki pengaruh lebih besar terhadap keterampilan menulis daripada kompetensi kolokasi reseptif. Pengajaran kolokasi (terutama untuk penguasaan kompetensi produktif) perlu diberikan untuk meningkatkan kualitas tulisan pemelajar.
\end{abstract}

Kata kunci: kolokasi, kompetensi produktif, kompetensi reseptif, kompetensi komunikasi kualitatif

\begin{abstract}
Collocation is considered to be the hallmark of learners' language quality. Collocational competence is a crucial element of native speakers' communicative competence (Bazzaz \& Samad, 2011). Much research has been conducted on collocational competence, but little investigates it more specifically by dividing it into productive and receptive competence (Henriksen, 2013). This research aims to investigate Indonesian EFL learners' productive and receptive competences in $v+n$ and adj $+n$ types of collocation and the relationship between the competences with their writing skills. For the purposes, this largely qualitative research applied three instruments: blank-filling test of English collocations to obtain the data about the learners' level of collocational productive competence, multiple-choice test of English collocations to reveal their collocational receptive competence and writing test to disclose their writing skills. The analyses of the data from the three instruments showed that the subjects' scores of productive competence in $v+n$ and adj $+n$ types of collocation were moderate, but lower than those of receptive competence in both types of collocation. The analyses also revealed that the level of subjects' writing competence stood at level 4 (moderately good) with some aspects to improve. Further analyses indicated that productive competence had more influences than receptive competence on writing skills. Thus, teaching collocation to gain its productive competence especially is necessary to increase learners' writing quality.
\end{abstract}

Key words: collocation, productive competence, receptive competence, qualitative, communicative competence. 


\section{PENDAHULUAN}

Kolokasi telah menjadi fokus perhatian para guru bahasa dan pemerhati pendidikan bahasa Inggris sebagai bahasa asing dan bahasa kedua. Menurut Hsu (2007), perhatian ini muncul bersama terbitnya buku karangan Lewis (1993), The Lexical Approach, yang membahas secara mendalam ekspresi multikata (yang unsur utamanya adalah kolokasi). Mahvelati \& Mukundan (2012) bahkan mengatakan jauh sebelumnya banyak peneliti telah mengungkapkan kolokasi sebagai komponen penting kompetensi kebahasaan seorang pemelajar bahasa.

Walaupun banyak peneliti yang telah mengkaji kolokasi, penelitian mereka dianggap terlalu beragam sehingga kehilangan fokus, dan temuannya kurang memiliki nilai praktis bagi para guru dan praktisi di bidang pembelajaran (Hsu, 2007: 193). Beberapa peneliti (Farghal \& Obiedat, 1995; Zughoul \& Abdul-Fattah, 2003) hanya menelaah pengetahuan kolokasi pemelajar bahasa Inggris sebagai bahasa asing atau bahasa kedua. Peneliti lain (Kuo, 2009; Saudin, 2014; Yan, 2010) menganalisis kesalahan pemelajar bahasa Inggris jenis ini dalam membentuk kolokasi. Ellis (2001), Koya (2006) dan Nation (2001) melaporkan bahwa kolokasi merupakan unsur penting dalam berbahasa dan keterampilannya menjadi pembeda bahasa penutur asli dan bukan penutur asli.

Kajian kolokasi yang lebih fokus deangan nilai praktis yang lebih besar, belum banyak dilakukan (Hsu, 2007). Penelitian dimaksud adalah kajian pengetahuan kolokasi pemelajar bahasa Inggris sebagai bahasa asing/kedua yang dikaitkan dengan keterampilan berbahasa khusus seperti Speaking, Listening, Reading dan Writing. Tercatat baru beberapa peneliti yang telah mengkajinya seperti Hsu (2007), yang mengaitkan jenis dan frekuensi penggunaan kolokasi dengan nilai online writing test dan Zhang (1993), yang mengaitkan kompetensi kolokasi dengan kualitas paper-and-pencil writing test; Sung (2003), yang menghubungkan kompetensi kolokasi dengan keterampilan speaking; dan Al-Zahrani (1998) serta Bonk (2000), yang merelasikan kompetensi ini dengan general English proficiency.

Penelitian dengan judul Kajian Kompetensi Kolokasi dan Keterampilan Menulis ini memiliki arah seperti penelitian di atas. Penelitian menghubungkan kompetensi kolokasi dengan keterampilan menulis subjek yang dihasilkan dalam writing test dalam kelas 
reguler. Meskipun demikian, penelitian ini memiliki perbedaan dari penelitian sebelumnya. Penelitian ini mencoba melihat kolokasi sebagai suatu kompetensi secara lebih khusus dengan membaginya ke dalam kompetensi kolokasi produktif dan reseptif. Dalam konteks ini, dikatakan bahwa jumlah penelitian yang telah dilakukan masih sangat terbatas (Henriksen, 2013).

Pembagian kompetensi kolokasi menjadi dua jenis penting. Pembagian tersebut dapat menginformasikan tingkat penguasaan kolokasi yang lebih akurat dan lebih mencerminkan kompetensi kolokasi pemelajar sesungguhnya. Kompetensi kolokasi produktif menunjukkan kompetensi yang bersifat aktif. Kompetensi kolokasi produktif ini dikuasai apabila pemelajar mampu menggunakan kolokasi secara benar atau berterima (acceptable) dalam aktivitas berbahasa produktif yaitu menulis dan berbicara. Sementara itu, kompetensi kolokasi reseptif bersifat pasif. Menurut Brashi (2010), pemelajar bahasa Inggris sebagai bahasa asing/kedua mempunyai kompetensi kolokasi ini apabila bisa mengenali kolokasi dan maknanya hanya ketika kolokasi tersebut mereka baca dan dengar, dua aktivitas yang juga bersifat reseptif.

Sejauh ini, baru terdapat dua penelitian (Brashi, 2010; Koya, 2003) yang mengkaji dua jenis kompetensi kolokasi tersebut. Koya meneliti hubungan antara perkembangan pengetahuan keduanya dengan perkembangan pengetahuan vocabulary secara umum, cara pemerolehan kedua jenis pengetahuan kolokasi tersebut pada sejumlah pemelajar dengan level bahasa Inggris yang berbeda, dan peran keduanya terhadap keberhasilan dalam berkomunikasi. Sementara itu, Brashi menelaah sebatas pengetahuan sejumlah pemelajar bahasa Inggris mengenai keduanya. Kedua penelitian di atas tidak mengaitkan dua pengetahuan kolokasi tersebut dengan keterampilan menulis sebagaimana yang dilakukan di dalam penelitian ini. Lebih jauh, penelitian Brashi (2010) dan Koya (2003) juga hanya berfokus pada satu tipe kolokasi, yaitu v+n. Sementara, penelitian ini mengambil fokus dua tipe kolokasi yaitu $v+n$ dan adj+n, dua jenis kolokasi utama yang menurut Saudin (2014), Siyanova \& Schmitt (2008) dan Yan (2010) paling banyak dipakai dalam teks para pemelajar. Dua tipe kolokasi itu juga paling banyak direalisasikan secara keliru (sekitar 50\% dan 25\%) meskipun kemahiran bahasa Inggris mereka sudah dikelompokkan ke dalam tingkat Advanced. 
Dengan fokus pada dua jenis kompetensi kolaksi dan kaitannya dengan keterampilan menulis, penelitian ini diharapkan memberikan kontribusi bagi teori kolokasi dan menjadi sumber informasi praktis bagi efektivitas pengajaran Writing. Untuk menggambarkan arahnya secara lebih eksplisit, penelitian ini dipandu oleh pertanyaan penelitian berikut:

1. Seberapa tinggi tingkat pengetahuan/kompetensi kolokasi produktif dan reseptif subjek penelitian dalam lingkup dua tipe kolokasi $v+n$ dan adj $+n$ ?

2. Seberapa tinggi tingkat keterampilan menulis mereka?

3. Bagaimana pengaruh tingkat kompetensi kolokasi produktif dan reseptif dalam dua tipe kolokasi ini terhadap keterampilan menulis mereka?

\section{TINJAUAN PUSTAKA}

\section{Kolokasi}

Istilah kolokasi diperkenalkan pertama kali oleh Palmer (1933) dan dibawa ke ranah teori kebahasaan (linguistics) oleh Firth (1957). Istilah tersebut berasal dari kata kerja bahasa Latin 'collocare,' yang bermakna 'to set in order / to arrange', merangkai atau menyusun (Hsu, 2007; Mahvelati \& Mukundan, 2012). Lewis (2000, hal. 74 dalam Miyakoshi, 2009) secara singkat mendefinisikan kolokasi sebagai dua kata atau lebih yang cenderung muncul bersama, "two or more words that tend to co-occur together." Kolokasi juga dikenal sebagai pasangan kata yang terdengar alami dan tertulis dengan tingkat keterbacaan yang tinggi karena sering bersanding sehingga menjadi padu dalam kesatuan ekspresi.

Kompetensi kolokasi merupakan aspek penting kemampuan berkomunikasi penutur asli, dan mencakup pengetahuan mengenai kosa kata yang lazim dan tidak lazim dimunculkan berpasangan (Bazzaz \& Samad, 2011). Kompetensi ini dianggap pembeda antara bahasa Inggris penutur asli dengan bahasa Inggris penutur asing (Koya, 2006; Nation, 2001). Penutur asli mempunyai intuisi untuk mengetahui suatu kata bisa dipasangkan dengan pilihan kata tertentu tetapi tidak bisa dengan kata tertentu lainnya walaupun pilihan kata tersebut sinonim. Dalam konteks bahasa Indonesia, pasangan kata membuat kerusakan, sehelai/selembar kain, setia kawan dan pekerja keras terdengar 
alami. Terdengar aneh kalau kita sebagai penutur asli mendengar pemelajar bahasa Indonesia mengatakan misalnya *mengerjakan kerusakan, *seutas kain, setia *teman, dan pekerja *kuat.

Penutur asing sulit menguasai kompetensi kolokasi ini walaupun sudah lama mempelajari suatu bahasa dan level proficiency mereka sudah bagus. Kenyataan tersebut telah diungkapkan oleh banyak penelitian (lihat Mahvelati \& Mukundan, 2012). Hal ini disebabkan penutur asing tidak/kurang memiliki intuisi untuk memasangkan kata-kata dengan tepat dan benar. Sebagian besar mereka tidak secara rutin menggunakan bahasa asing yang dipelajarinya dan tidak terpapar oleh bahasa tersebut secara berkesinambungan. Penguasaan pengetahuan kolokasi dinilai sebagai indikator penting untuk tingkat kemahiran berbahasa (Bazzaz \& Samad, 2011; Hsu, 2007; Zhang, 1993). Sebaliknya, pengetahuan kolokasi yang lemah akan membuat bahasa si pemelajar terdengar janggal (McCarthy, 1990; McArthur, 1992).

Benson et al. (1997; lihat juga Saudin, 2013; Yan, 2010) membagi kolokasi ke dalam dua jenis utama: kolokasi leksikal dan kolokasi gramatikal. Kolokasi leksikal adalah sebuah frase yang berisi pasangan kombinasi sintagmatik antara kata konten (kata kerja, kata benda, kata sifat dan kata keterangan) seperti draw a conclusion $(v+n)$, heavy traffic $(\operatorname{adj}+n)$, human resources $(n+n)$, affect deeply $(v+a d v)$, strikingly different $(\operatorname{adv}+$ adj), go blind $(v+\operatorname{adj})$, doctors diagnose $(n+v)$ dan crystal clear $(n+\operatorname{adj})$. Kolokasi gramatikal merupakan pasangan kombinasi yang terdiri atas kata konten (terutama kata benda, kata kerja atau kata sifat) dengan kata fungsi (kata depan/preposisi) dan sering mencakup struktur gramatikal adj/n + that clause/to infinitive. Contoh-contoh kolokasi gramatikal ini misalnya argument about $(n+p r e p)$, by accident $(p r e p+n)$, depend on ( $v+$ prep), angry with (adj+prep), a pride of lions (quantifier+n) dan back to (prep+prep).

Menurut sebagian besar ahli linguistik selain ditentukan oleh ciri susunan sintagmatik kata-kata pembentuknya, kolokasi juga ditetapkan oleh ciri restrictedness (keterbatasan), semantic transparency (makna yang tetap literal), dan posisinya yang berada di antara idioms (ungkapan) dan free (word) combinations (kombinasi bebas) dalam sebuah kontinum (Howarth, 1998 dalam Miyakoshi, 2009).

Kombinasi antara kata break (yang disebut collocate, perangkai pokok) dengan kata benda seperti news dan promise (yang disebut node/cluster, perangkai ikutan), dianggap 
sebagai kolokasi karena bersipat restricted. Kata kerja break tidak dapat diganti oleh kata lain yang maknanya mirip seperti inform atau violate. Tetapi, kata break yang dipasangkan dengan kata benda seperti glasses, a vase, dan banyak frase nominal lainnya tidak dianggap sebagai kolokasi. Pasangan kata tersebut disebut free word combinations, terbentuk hanya untuk mengikuti aturan umum syntax bahwa kata perlu digabung untuk naik ke level linguistik yang lebih tinggi.

Pengertian semantic transparency merujuk pada kenyataan bahwa kedua kolokasi break the news dan break the promise mempunyai konstituen kata yang maknanya masih transparan, masih bisa dipahami dari kata-kata penyusunnya. Kolokasi berbeda dengan idioms (misalnya break a leg) yang bersifat 'non-compositional' (maknanya berbeda dengan kata penyusunnya). Di dalam penelitian ini, idioms - sebagaimana free word combinations - tidak diperhitungkan sebagai kolokasi meskipun batas antara idiom, kolokasi dan kombinasi bebas tidak begitu jelas (Miyakoshi, 2009).

\section{Kompetensi Kolokasi}

Selain berdasar pada konsep pasangan kata, kolokasi juga bisa dipilah berdasarkan sudut pandang bahwa kolokasi adalah suatu pengetahuan atau kompetensi. Dengan dasar ini, Alsakran (2011), Koya (2003) dan Pei (2008) mengelompokkan kompetensi kolokasi ke dalam kompetensi produktif dan reseptif. Pengelompokan ini sebetulnya dipengaruhi oleh gagasan Nation (2001) yang memilah pengetahuan mengenai kata ke dalam pengetahuan reseptif dan produktif.

Kompetensi kolokasi produktif adalah pengetahuan yang membuat pemelajar mampu memproduksi kolokasi dalam ujaran atau tulisan. Alsakran (2011, hal. 11) menulis "Productive knowledge is the ability to use and have access to words in speech and writing." Pemelajar mempunyai kompetensi kolokasi produktif apabila mengetahui secara praktis ketika berujar atau menulis bahwa kata benda homework sebagai sebuah node/cluster, misalnya, harus dipasangkan dengan kata kerja do (atau bentuk derivatifnya seperti does, did, doing) sebagai colocatenya. Tidak masalah apabila pemelajar membuat kesalahan derivatif tersebut (lihat Brashi 2010). Pada sisi lain, kompetensi kolokasi reseptif adalah pengetahuan pemelajar dalam hal mengenali bahwa sebuah collocate dapat berpasangan dengan node atau cluster tertentu tetapi tidak dengan cluster yang lain. 
Pengetahuan reseptif ini bersifat hanya sebatas kemampuan mengidentifikasi pasangan kata (kolokasi) ketika kolokasi tersebut didengar atau dibaca.

\section{Keterampilan Menulis}

Di abad ke-21 sangat penting membekali pemelajar dengan keterampilan menulis yang baik untuk meraih keberhasilan (Hyland, 2003). Kemampuan menyampaikan gagasan dan informasi secara efektif melalui jaringan digital global (media cetak dan elektronik) sangat bergantung pada kemampuan menulis, terutama dalam bahasa Inggris. Esselink (2000 dalam Hatim \& Munday, 2004) juga menunjukkan adanya kebutuhan yang tinggi akan penerjemahan dan penulisan yang efektif untuk teks pemasaran dan bentuk komunikasi tertulis lainnya antara perusahaan multinasional.

Di dalam pengajaran bahasa asing/kedua, pengajaran keterampilan menulis sangat direkomendasikan dan menjadi bahasan banyak makalah, artikel, disertasi, buku dan bahkan jurnal tersendiri (Brown, 2004). Di Indonesia pun, keterampilan menulis ini mendapatkan perhatian besar dari pemerintah, memperoleh tempat yang sentral di dalam kurikulum pengajaran bahasa Inggris walaupun pergantian kurikulum telah terjadi beberapa kali (Emilia, 2010). Namun, keterampilan menulis sulit untuk dikuasai, terutama oleh para pemelajar bahasa Inggris (Brown, 2004). Ahmed (2010) mengklaim bahwa tulisan para pemelajar di belahan dunia mana pun, ternyata buruk walau berbagai pendekatan dan metode pengajaran keterampilan menulis terus dikembangkan untuk mencari teknik yang efektif. Setiap anak di negara maju belajar kiat-kiat menulis dalam bahasa asli mereka, tetapi sangat sedikit yang mampu mengutarakan gagasannya secara jelas dengan susunan logis, sistematis dan mampu mencapai tujuan yang dikehendaki (Brown, 2004). Di Indonesia pun, jarang ada pemelajar yang mampu menulis dalam bahasa Indonesia dengan baik, apalagi dalam bahasa Inggris. Maka penelitian ini, yang menjadikan keterampilan menulis sebagai salah satu variabelnya, mempunyai manfaat yang besar.

\section{METODE PENELITIAN}

Penelitian ini pada dasarnya menggunakan metoda kualitatif, yang menurut Sugiyono (2010) juga disebut penelitian interpretatif. Holliday (2007) menegaskan bahwa karena fenomena atau realitas itu bagi peneliti sesungguhnya mengandung misteri yang 
harus diungkapkan, maka untuk itu mereka tidak bisa lain kecuali melakukan interpretasi. Penganut paham ini yakin bahwa ilmu dan hakekat makna berasal dari tindakan interpretasi. Jadi, tidak ada pengetahuan yang obyektif, yang bebas dari pemikiran dan nalar manusia. Penelitian juga memanfaatkan instrumen metoda kuantitatif seperti tabel untuk menampilkan angka dan prosentase hasil analisis/ temuan penelitian yang kemudian dibahas secara mendalam (secara kualitatif). Penelitan juga dirancang sebagai studi kasus, mengkaji beberapa fenomena dalam suatu waktu dan tempat tertentu dan mengaplikasikan teknik pengumpulan data yang melibatkan sumber data seperti dokumen dan teks. Hal ini untuk memastikan bahwa peneliti memperoleh informasi lengkap dan rinci mengenai isu yang diteliti sehingga validitas proses penelitian dapat dicapai (Stake 1995; Yin, 1984).

\section{Tempat dan Subjek Penelitian}

Penelitian mengambil tempat di Jurusan Bahasa Inggris Politeknik Negeri Bandung. Tempat penelitian ini dipilih karena peneliti adalah tenaga pengajar di sana sehingga mudah mendapatkan akses terhadap subjek penelitian, dokumen yang diperlukan dan hal-hal lain terkait pelaksanaan penelitian. Subjek yang dilibatkan berasal dari dua kelas (49 mahasiswa) Jurusan Bahasa Inggris tingkat dua semester empat. Mereka dipilih dengan pertimbangan bahwa mereka telah mendapatkan pengetahuan teori dan praktik menulis pada semester sebelumnya. Mereka telah memproduksi berbagai tipe teks, termasuk tipe argumentatif, jenis teks yang mereka buat di dalam writing test yang menjadi salah satu sumber data penelitian.

\section{Sumber Data}

Dalam penelitian ini, sumber data didapat dari tiga instrumen (instrumen tidak dilampirkan). Instrumen pertama adalah Tes 1 yang berisi 40 kalimat soal berbentuk fill in the blanks untuk dilengkapi sendiri oleh mahasiswa. Dua puluh soal dilengkapi dengan kata kerja untuk membentuk kolokasi $\mathrm{v}+\mathrm{n}$ dan 20 soal lainnya dengan kata sifat sebagai collocate untuk membentuk kolokasi adj+n. Tes berbentuk fill in the blanks ini lazim digunakan untuk mengukur tingkat kompetensi kolokasi produktif (Mahvelati \& Mukundan, 2012). Tes 1 ini berlangsung selama 35 menit. Instrumen kedua adalah Tes

2 , berbentuk multiple-choice yang umum dipakai untuk menilai tingkat pengetahuan kolokasi reseptif (Mahvelati \& Mukundan, 2012). Tes 2 praktis sama dengan Tes 1. 
Hanya ada satu perbedaan yaitu di dalam Tes 2 pilihan jawaban soal diberikan sehingga waktunya lebih singkat yaitu 25 menit. Nilai 100 diberikan kepada subjek apabila menjawab benar semua untuk 20 soal.

Pembuatan soal tes 1 dan Tes 2 ini merujuk model yang sudah digunakan oleh peneliti lain (Brashi, 2010; Koya 2003). Namun, model lebih jauh diperbaiki berdasarkan Kamus Oxford Collocations Dictionary (McIntosh, 2009) dan sumber teks online seperti British National Corpus (BNC). BNC adalah data base teks otentik yang luar biasa besar dan menyimpan informasi contoh penggunaan kata dan frase dalam kalimat. Apabila sebuah frase sering muncul dalam contoh penggunaan di sana, maka ini membuktikan frase tersebut termasuk sebuah kolokasi yang well-formed (Kuo, 2009). Tes juga dibuat dengan mempertimbangkan tingkat general proficiency bahasa Inggris dari subjek penelitian, yaitu tingkat Intermediate.

Instrumen ketiga adalah Tes 3 yaitu Writing Test, yang menghasilkan sumber data berupa teks tulisan yang kemudian dinilai. Untuk pembuatan instrumen tersebut, model writing test dari Hsu (2007), sebuah model tes yang mengikuti Writing Test TOEIC, dijadikan rujukan. Writing Test ini berisi instruksi untuk menulis pendapat dan argumentasi peserta tes mengenai isu terkait pelatihan yang biasa diberikan perusahaan kepada karyawan barunya. Tes dilengkapi dengan writing prompts (petunjuk penulisan) singkat. Tes 3 berlangsung selama 55 menit. Setelah tes berakhir, kualitas tulisan dianalisis dan diberi nilai dengan mengikuti panduan scoring guide by Criterion (7.1), ETS.

\section{HASIL DAN PEMBAHASAN}

\section{Analisis Tes Kompetensi Kolokasi Produktif (Tes 1)}

Tiga buah test (Test 1, Tes 2 dan Tes 3) menjadi sumber data utama dari penelitian ini. Analisis kemudian dilakukan dan hasil serta bahasannya satu persatu akan diuraikan. Berikut ini hasil analisis terhadap tes kompetensi kolokasi produktif (Tes 1) yang ditabulasi pada Tabel 1. Tabel menampilkan kategori capaian tes dan skor capaian subjek yang mencerminkan tingkat kompetensi kolokasi produktif mereka untuk tipe kolokasi $v+n$ dan $a d j+n$. 
Tabel 1

Hasil Tes Kompetensi Kolokasi Produktif (Tes 1)

\begin{tabular}{|c|c|c|c|c|c|c|}
\hline \multirow{2}{*}{} & \multicolumn{6}{|c|}{ Kategori Capaian Tes } \\
\cline { 2 - 7 } & \multicolumn{2}{|c|}{ Tinggi } & \multicolumn{2}{c|}{ Sedang } & \multicolumn{2}{c|}{ Rendah } \\
\cline { 2 - 7 } & $v+n$ & $a d j+n$ & $v+n$ & $a d j+n$ & $v+n$ & adj $+n$ \\
\hline $\begin{array}{c}\Sigma \text { Subjek Peraih } \\
\text { Kategori }\end{array}$ & 15 & 2 & 22 & 24 & 12 & 23 \\
\hline $\begin{array}{c}\text { Prosentasi } \\
\text { Tes Kompetensi Kolokasi Produktif }\end{array}$ & 40,6 & 44,9 & 49 & 24,5 & 47 \\
\hline Tipe v+n & & & 67 \\
\hline Tes Kompetensi Kolokasi Produktif \\
Tipe adj+n \\
Rerata
\end{tabular}

Terdapat 15 subjek dari total $49(30,6 \%)$ yang mendapat capaian tinggi dalam tes kompentensi kolokasi produktif tipe $v+n$. Namun, hanya ada dua subjek (4\%) yang mendapatkan nilai tinggi dalam tes kompetensi kolokasi produktif tipe $a d j+n$. Sementara itu, subjek yang memperoleh nilai sedang dalam tes kompetensi kolokasi produktif tipe $v+n$, berjumlah $22(44,9 \%)$. Untuk tes kompetensi kolokasi produktif tipe $a d j+n$, subjek yang mendapat nilai sedang berjumlah sedikit lebih banyak yaitu 24 (49\%). Terkait peserta dengan nilai rendah dalam tes kolokasi produktif $v+n$, tercatat ada 12 orang $(24,4 \%)$. Di sisi lain, peserta dengan nilai rendah tes kolokasi produktif $a d j+n$ berjumlah $23(47 \%)$. Perbedaan kategori capaian ini menunjukkan kompetensi kolokasi produktif tipe $a d j+n$ lebih sulit bagi subjek daripada soal tes kompetensi kolokasi produktif tipe $v+n$.

Data capaian tes kompetensi kolokasi produktif dari 49 subjek penelitian ini juga memperlihatkan bahwa tingkat kompetensi kolokasi produktif mereka berada pada kisaran angka 62,1. Skor adalah rerata dari nilai 67 (nilai tes kompetensi kolokasi 
produktif subjek untuk tipe $v+n$ ) dan 57,2 (nilai tes kompetensi kolokasi produktif subjek untuk tipe $a d j+n)$. Skor capaian tersebut memperlihatkan kompetensi kolokasi mereka tidak mengecewakan bahkan bisa dikatakan cukup bagus karena berada di atas angka median 50.

\section{Analisis Tes Kompetensi Kolokasi Reseptif (Tes 2)}

Hasil tes kompetensi kolokasi reseptif (Tes 2) dirangkum dalam Tabel 2 berikut. Tabel menampilkan kategori capaian tes dan skor capaian yang mencerminkan tingkat kompetensi reseptif subjek untuk jenis kolokasi $v+n$ dan $a d j+n$.

Tampak bahwa terdapat 39 subjek peserta dari total $49(79,6 \%)$ memperoleh nilai tinggi dalam tes kompentensi kolokasi reseptif tipe $v+n$. Untuk tes kompentensi kolokasi reseptif tipe $a d j+n$, hanya 18 subjek $(36,7 \%)$ yang memperoleh nilai tinggi. Sementara itu, subjek peserta tes kompetensi kolokasi reseptif tipe $v+n$ yang memperoleh nilai sedang berjumlah $9(18,4 \%)$ dan berjumlah $27(55,1 \%)$ yang mendapat nilai sedang untuk tes kompetensi kolokasi reseptif tipe $a d j+n$. Akan halnya subjek dengan nilai rendah dalam tes kolokasi reseptif $v+n$, tercatat 1 orang subjek (2\%) dan 4 orang subjek $(8,2 \%)$ yang memperoleh nilai rendah dalam tes kolokasi reseptif $a d j+n$. Perbedaan kategori capaian subjek ini menunjukkan bahwa kompetensi reseptif kolokasi tipe $a d j+n$ lebih sukar bagi mereka daripada kompetensi reseptif kolokasi tipe $v+n$.

Hasil tes pada Tabel 2 juga menunjukkan gambaran bahwa tingkat kompetensi kolokasi reseptif subjek berada pada kisaran angka 80,7, yang merupakan rerata dari 86 (capaian tes kompetensi kolokasi reseptif tipe $v+n$ ) dan 75,5 (capaian tes kompetensi kolokasi reseptif tipe $a d j+n)$. Raihan nilai ini memperlihatkan kompetensi kolokasi reseptif mereka yang tinggi karena capaian berada di atas angka 80, yang dalam praktik penilaian dengan skala 100 lazim dikelompokkan ke dalam nilai huruf tertinggi yaitu A. 
Tabel 2

Hasil Tes Kompetensi Kolokasi Reseptif (Tes 2)

\begin{tabular}{|c|c|c|c|c|c|c|}
\hline & \multicolumn{6}{|c|}{ Kategori Capaian Tes } \\
\hline & \multicolumn{2}{|c|}{ Tinggi } & \multicolumn{2}{|c|}{ Sedang } & \multicolumn{2}{|c|}{ Rendah } \\
\hline & $v+n$ & $\operatorname{adj}+n$ & $v+n$ & $a d j+n$ & $v+n$ & $a d j+n$ \\
\hline $\begin{array}{l}\Sigma \text { Subjek Peraih } \\
\text { Kategori }\end{array}$ & 39 & 18 & 9 & 27 & 1 & 4 \\
\hline Prosentasi & 79,6 & 36,7 & 18,4 & 55,1 & 2 & 8,2 \\
\hline \multicolumn{7}{|c|}{ Skor Capaian Subjek } \\
\hline \multicolumn{4}{|c|}{$\begin{array}{c}\text { Tes Kompetensi Kolokasi Reseptif } \\
\text { Tipe } v+n\end{array}$} & \multicolumn{3}{|c|}{86} \\
\hline \multicolumn{4}{|c|}{$\begin{array}{c}\text { Tes Kompetensi Kolokasi Reseptif } \\
\text { Tipe adj+n }\end{array}$} & \multicolumn{3}{|c|}{75,5} \\
\hline \multicolumn{4}{|c|}{ Rerata } & \multicolumn{3}{|c|}{80,7} \\
\hline
\end{tabular}

Temuan umum penelitian ini bahwa kompetensi kolokasi reseptif pemelajar lebih tinggi daripada pengetahuan kolokasi produktif mereka, mendukung hasil penelitian yang telah dilakukan oleh Brashi (2010), Henriksen (2013) dan Koya (2003). Brashi secara spesifik mengungkapkan hanya 38\% kolokasi produktif berhasil dibuat pemelajar secara well-formed. Juga pemelajar mampu membuat $79 \%$ kolokasi reseptif $v+n$ yang acceptable. Bandingkan dengan temuan penelitian ini yang mengungkapkan angka keberhasilan 62,1\% untuk kolokasi produktif dan 80,7\% untuk kolokasi reseptif.

Untuk kolokasi reseptif, penelitian Brashi dan penelitian ini tidak menunjukkan perbedaan angka capaian yang besar. Namun, perbedaan signifikan ada pada angka capaian kolokasi produktif (38\% dalam penelitian Brashi, 62,1\% dalam penelitian ini). Minimal ada dua hal yang menyebabkan perbedaan tersebut. Pertama, keterampilan kolokasi produktif subjek di dalam penelitian ini kemungkinan memang lebih tinggi daripada subjek di dalam penelitian Brashi. Kedua, soal tes dalam penelitian Brashi lebih 
sulit. Brashi misalnya meminta subjek penelitiannya untuk mencari collocate untuk node seperti a pact, war dan caution.

Dari uraian temuan dapat disimpulkan bahwa kompetensi kolokasi produktif lebih sulit dikuasai daripada kompetensi reseptif. Henriksen (2013) mengatribusikan kelemahan kompetensi kolokasi produktif pemelajar ini kepada pengaruh pengajaran. Banyak pengajar cenderung menekankan individual words dan sering tidak memiliki latihan yang bermanfaat untuk membangkitkan kesadaran pemelajar akan kolokasi. Menurut Wray (2002 dalam Boers et al. 2014), kelemahan tersebut juga karena pemelajar terbiasa melihat kata-kata yang dipisah oleh spasi sehingga perhatian mereka lebih terfokus pada setiap individu kata ketimbang pada ekspresi multikata.

\section{Analisis Tes Keterampilan Menulis (Tes 3)}

Untuk mengetahui keterampilan menulis subjek, hasil Tes 3 mereka yang berupa tulisan dinilai secara holistik dengan menggunakan panduan scoring guide by Criterion (7.1), ETS. Hasil penilaian keterampilan menulis mereka ditampilkan di dalam Tabel 3 berikut. Di dalam tabel, nilai keterampilan menulis mereka dikelompokkan ke dalam kategori nilai tinggi (skor 5 dan 6), sedang (skor 3 dan 4) dan rendah (skor 1 dan 2).

Tabel memperlihatkan sebanyak 19 peserta dari total 49 (38,8\%) memperoleh nilai tinggi dalam tes menulis. Sementara itu, 25 subjek (51\%) mendapatkan nilai sedang dalam tes keterampilan menulis ini. Peserta tes dengan skor sedang ini tampak menjadi mayoritas. Untuk nilai rendah, relatif sedikit peserta tes keterampilan menulis ini yang mendapatkannya. Dari 49 peserta, hanya 5 atau 10,2\% saja yang termasuk ke dalam kategori penulis yang lemah. Perlu ditekankan bahwa tidak ada satu pun peserta yang termasuk ke dalam kategori ini, memperoleh nilai 1.

Tabel 3

Kategorisasi Hasil Tes Menulis Teks Argumentatif (Tes 3)

\begin{tabular}{|c|c|c|c|}
\hline \multirow{2}{*}{} & \multicolumn{3}{|c|}{ Kategori Capaian Tes 3 Subjek } \\
\cline { 2 - 4 } & Tinggi & Sedang & Rendah \\
\hline$\Sigma$ Subjek & 19 & 25 & 5 \\
\hline Prosentasi & 38,8 & 51 & 10,2 \\
\hline
\end{tabular}


Gambaran capaian peserta tes di atas menunjukkan secara umum mereka mempunyai keterampilan menulis baik. Skor rerata capaian keterampilan menulis mereka menurut instrumen yang digunakan yaitu scoring guide by Criterion (7.1), ETS adalah 4,1. Deskriptor nilai 4 mengatakan bahwa walaupun tulisan mereka sudah baik, tetapi masih perlu diolah agar lebih persuasif dan efektif dalam mengkomunikasikan gagasan. Dikatakan pula bahwa di dalam tulisan, sejumlah instruksi diabaikan, gagasan yang dikemukakan terlalu umum, terjadi pengulangan gagasan, tulisan diorganisasikan dengan cukup baik tetapi subjek kurang dalam memberikan bukti/alasan/contoh untuk mendukung posisi yang diambilnya, dan subjek mampu mengemukakan maksudnya tetapi perlu menggunakan bahasa dengan lebih pas atau meyakinkan.

\section{Pengaruh Tingkat Kompetensi Kolokasi Produktif dan Reseptif Terhadap Keterampilan Tulisan}

Untuk mengetahui pengaruh kompetensi kolokasi produktif dan reseptif terhadap keterampilan menulis, hasil tes subjek dikelompokkan ke dalam kategori tinggi (nilai $\geq$ 77,5). Demikian pula dengan nilai keterampilan menulis mereka. Keterampilan menulis yang dianggap tinggi adalah tulisan dengan skor 5 dan 6 seperti yang tertulis di dalam instrumen scoring guide by Criterion (7.1), ETS.

Tabel 4

Pengaruh Kompetensi Kolokasi Produktif \& Reseptif

Terhadap Keterampilan Menulis

\begin{tabular}{|l|c|c|c|c|}
\hline & $\begin{array}{c}\text { Komp. Kolokasi } \\
\text { Produktif Tinggi }\end{array}$ & $\begin{array}{c}\text { Kualitas } \\
\text { Tulisan Tinggi }\end{array}$ & $\begin{array}{c}\text { Komp. Kolokasi } \\
\text { Reseptif Tinggi }\end{array}$ & $\begin{array}{c}\text { Kualitas } \\
\text { Tulisan Tinggi }\end{array}$ \\
\hline$\sum$ Subjek & 6 & 5 & 35 & 17 \\
\hline $\begin{array}{l}\text { Prosentasi } \\
\text { Pengaruh }\end{array}$ & $83 \%$ & & \multicolumn{2}{|c|}{$48 \%$} \\
\hline
\end{tabular}

Tampak pada Tabel 4 bahwa terdapat total enam peserta memperoleh nilai tes kolokasi produktif yang tinggi dan lima dari mereka mendapatkan nilai yang juga tinggi dalam tes menulis. Namun, untuk tes kolokasi reseptif, dari 35 peserta yang memperoleh nilai tinggi, hanya 17 dari mereka juga memperoleh nilai menulis tinggi. Jadi, 
sebagaimana terlihat pada baris terakhir tabel, pengetahuan kolokasi produktif memiliki pengaruh yang lebih besar daripada pengetahuan kolokasi reseptif terhadapketerampilan menulis. Pengaruh pengetahuan kolokasi produktif tercatat $83 \%$, sementara pengaruh pengetahuan kolokasi reseptif sebesar 48\%, lebih kecil bahkan hampir mendekati separuh dari prosentasi pengaruh pengetahuan kolokasi produktif.

Sejauh yang peneliti ketahui belum ada penelitian sebelumnya yang membahas keterkaitan antara kedua jenis kompetensi ini dengan keterampilan atau kualitas tulisan. Penelitian ini menunjukkan dengan lebih spesifik bahwa kompetensi kolokasi produktiflah yang sesungguhnya bertanggung jawab atas tingkat keterampilan berbahasa pemelajar. Ini suatu sumbangan cukup berharga terhadap teori mengenai kolokasi. Selama ini, kompetensi kolokasi yang dilihat secara umumlah yang berperan penting bagi kualitas tulisan (Hsu, 2007; Zhang, 1993), terhadap kefasihan berbicara (Sung, 2003 dalam Hsu, 2007) dan bahkan terhadap kualitas keterampilan berbahasa Inggris secara umum atau general English proficiency (Al-Zahrani, 1998 dalam Hsu, 2007; Bonk, 2000). Dengan demikian, pengetahuan kolokasi produktif ini yang lebih perlu untuk diajarkan kepada pemelajar untuk dikuasai.

\section{SIMPULAN DAN SARAN}

Penelitian ini memperlihatkan bahwa kompetensi kolokasi mahasiswa Jurusan Bahasa Inggris Politeknik Negeri Bandung tidaklah mengecewakan. Dari nilai tes kompetensi kolokasi yang berisfat produktif yaitu 62,1 dan yang bersipat reseptif yaitu 80,7, maka rerata nilai kompetensi kolokasi mereka berada pada angka 71,4. Ini suatu capaian yang bagus. Capaian ini menunjukkan bahwa mereka mendapat exposure bahasa Inggris yang (sangat) baik di kelas, yang tentunya bersumber dari materi atau buku ajar yang digunakan dan dari pengajar mereka yang secara umum bisa disimpulkan mempunyai kompetensi bahasa Inggris yang baik sehingga mampu memberi contoh penggunaan bahasa Inggris yang 'native-like' dalam bentuk lisan dan tulisan.

Untuk keterampilan menulis, hasil yang mereka raih pun tidaklah buruk. Nilai yang mereka capai $(4,1)$ berdasarkan scoring guide resmi menunjukkan keterampilan menulis mereka berada pada kategori lebih dari cukup. Lebih jauh, penelitian ini membuktikan hubungan yang signifikan antara kompetensi atau pengetahuan kolokasi dengan 
keterampilan menulis, terutama kompetensi produktif (dengan nilai keterkaitan 83\%) dibandingkan dengan kompetensi reseptif (dengan nilai keterkaitan 48\%).

Karena keterkaitan antara penggunaan kolokasi dengan keterampilan menulis sangat jelas, penelitian ini sangat menganjurkan agar kolokasi diajarkan kepada pemelajar terutama dalam pelajaran Writing agar mereka dapat menjadi penulis handal. Bahkan para linguist dan praktisi pengajaran bahasa Inggris menekankan pengajaran kolokasi penting diintegrasikan bukan hanya dalam silabus keterampilan menulis tetapi juga dalam keterampilan atau skill berbahasa lainnya (lihat Mahvelati \& Mukundan, 2012).

Dengan mempertimbangkan karakter kolokasi yang umumnya mengandung konstituen kata yang lazim sehingga dapat lepas dari perhatian pemelajar, pengajaran kolokasi yang tepat adalah pengajaran eksplisit, explicit instruction, yang memberi penekanan akan pentingnya attention dan awareness (lihat Long \& Robinson, 1998; Schmidt, 2001). Pengajaran ini dapat mengarahkan perhatian pemelajar secara khusus ke arah fitur bahasa kolokasi sehingga mereka menyadari nilai istimewanya. Mereka menyadari bahwa kata dapat dipasangkan dengan kata lain, tapi janggal disandingkan dengan kata yang lainnya lagi walaupun keduanya sinonim. Kesadaran tersebut akan membawa mereka kepada kemungkinan yang lebih besar dalam menguasai kolokasi.

Lebih jauh, pengajaran kompetensi kolokasi harus dikembangkan, mencakup kolokasi tidak hanya tipe $v+n$ tetapi juga tipe lainnya, terutama $a d j+n$. Kolokasi $v+n$ memang lebih banyak direalisasikan secara keliru oleh pemelajar daripada kolokasi $a d j+n$ di dalam tulisan mereka. Namum tidak berarti bahwa tingkat keterampilan mereka dalam menggunakan kolokasi tipe $a d j+n$ lebih baik daripada tipe $v+n$. Penggunaan kata sipat dalam tulisan mereka relatif terbatas, hanya mengulang-ulang sekelompok kecil kata sipat dan berujung pada pembentukan kolokasi yang keliru/malformed. Dengan pertimbangan fakta tersebut, perhatian untuk pengajaran kolokasi $a d j+n$ ini, apabila tidak lebih besar, paling tidak harus sama besar dengan perhatian yang sudah diberikan kepada pengajaran kolokasi $v+n$. Penelitian ini juga menganjurkan analisis realisasi kolokasi yang melibatkan apa pun jenis kolokasi di dalam tulisan pemelajar, menarik untuk dilakukan. Penelitian semacam ini bisa mengungkapkan kompetensi kolokasi pemelajar secara lebih utuh. 


\section{UCAPAN TERIMA KASIH}

Peneliti mengucapkan terima kasih kepada Politeknik Negeri Bandung yang telah membiayai penelitian ini pada tahun anggaran 2017 dengan nomor kontrak: Nomor: 654.12/PL1.R7/LT/2017

\section{DAFTAR PUSTAKA}

Ahmed, A. H. 2010. Students' problems with cohesion and coherence in EFL essay writing in Egypt: Different perspectives. Literacy Information and Computer Education Journal (LICEJ), Volume 1, Issue 4, December 2010.

Alsakran, R.A. 2011. The productive and receptive knowledge of collocations by Advanced Arabic-speaking ESL/EFL learners. Unpublished Thesis, Colorado State University, Fort Collins, Colorado.

Al-Zahrani, M. S. 1998. Knowledge of English lexical collocations among male Saudi college students majoring in English at Saudi University. Unpublished doctoral dissertation, Indiana University of Pennsylvania, Pennsylvania, USA.

Bazzaz, F. E. \& Samad, A.A. 2011. The use of verb-noun collocations in writing stories among Iranian EFL learners. English Language Teaching 4. 3 (Sep 2011): 158-163.

Benson, M., Benson, E. \& Ilson, R. 1997. The BBI dictionary of English word combinations ( $2^{\text {nd }}$ edition). Amsterdam, The Netherlands: John Benjamins Publishing Company.

Boers, F., Lindstromberg, S. \& Eyckmans J. 2014. Some explanations for the slow acquisition of L2 collocations. Vigo International Journal of Applied Linguistics.

Bonk, W.J. 2000. Testing ESL learners' knowledge of collocations. (ERIC Document Reproduction Service No. ED 442 309).

Brashi, A. 2010. Collocability as a problem in L2 production. Reflections on English Language Teaching, Vol 8, No 1, 12-34.

Brown, H. D. 2004. Language assessment: Principle and classroom practices. New York: Pearson Education, Inc.

Creswell, J.W. 2007. Qualitative inquiry \& reseach design: Coosing among five approaches $\left(2^{\text {nd }} \mathrm{Ed}\right)$. Thousand Oaks, California: Sage Publication.

Ellis, N.C. 2001. Memory for language. In P. Robinson (Ed.), Cognition and second language instructions. Cambridge: Cambride University Press.

Emilia, E. 2010. Teaching writing: Developing critical learners. Bandung: Rizki Press.

Farghal, M. \& Obiedat, H. 1995. Collocations: A neglected variable in EFL. International Review of Applied Linguistics, 33 (4), 315-333.

Firth, J. R. 1957. Papers in linguistics 1934-1951, 177-189. 
Hatim, B. \& Munday, J. 2004. Translation: An advanced resource book. London and New York: Routledge.

Henriksen B. 2013. Research on L2 learners' collocational competence and development - a progress report. http://www.eurosla.org/monographs/ EM02/Henriksen.pdf

Holliday, A. 2007. Doing and Writing Qualitative Research $2^{\text {nd }}$ Ed. Thousand Oaks California: Sage Publications Ltd.

Hsu, J. 2007. Lexical collocations and their relations to the online writing of Taiwanese college English majors and non-English majors. Electronic Journal of Foreign Language Teaching, 4 (2), 192-209.

Hyland, K. 2003. Second Language Writing. Cambridge: Cambridge University Press.

Koya, T. 2003. A Study of Collocation in English and Japanese Noun-Verb Combinations. Intercultural Communication Studies XII-1 2003. www.uri.edu/iaics/content/2003v12n1/08\%20Taeko\%20Koya.pdf

Koya, T. 2006. What is the reality of collocation use by native speakers of English? Dialogue, 5, 1-18.

Kuo, C. L. 2009. An analysis of the use of collocation by intermediate EFL college

Lewis, M. 1993. The lexical approach. London: Language Teaching Publications.

Long, M., \& Robinson, P. 1998. Focus on form: Theory, research and practice. In C. Doughty, \& J. Williams (Eds.), Focus on form in classroom second language acquisition (15-41). Cambridge: Cambridge University Press.

Mahvelati, E. H. \& Mukundan, J. 2012. The role of cognitive style in the collocational knowledge development of Iranian EFL learners through input flood treatment. English Language Teaching 5. 10 (2012): 105-117.

McArthur, T. 1992. The Oxford companion to the English language. Oxford: Oxford University Press.

McCarthy, M. 1990. Vocabulary. Oxford: Oxford University Press.

McMillan, J.H., Schumacher, S. 2001. Research in education. A conceptual introduction. New York: Longman.

Miyakoshi, T. 2009. Investigating ESL learners' lexical collocations: The acquisition of verb+noun collocations by Japanese learners of English. Diambil pada 11 Juni 2014 dari www.ling.hawaii.edu/graduate/dissertations/ TomokoMiyakoshiFinal.pdf

Nation, I.S.P. 2001. Learning vocabulary in another language. Cambridge: Cambridge University Press.

Palmer, H.E. 1933. Second interim report on English collocations. Tokyo: Kaitakusha.

Pei, C. 2008. Review of empirical studies on collocation in the field of SLA. Celea Journal, 31(6), 72-81. http//www.celea.og.cn/teic/82/82-72.pdf

Saudin, H. 2013. The realization of cohesion in students' Argumentative writing performance. Unpublished Master Thesis, Indonesia University of Education, Bandung, Indonesia. 
Saudin, H. 2014. The realization of collocation in EFL students' written texts across three proficiency levels. In the Proceedings of the $61^{\text {st }}$ TEFLIN International Conference. Book 1, 367-370.

Schmidt, R.W. 2001. “Attention”. In P. Robinson (ed), Cognition and Second Language Instruction, 3-32. Cambridge: Cambridge University Press.

Siyanova, A., \& Schmitt, N. 2008. L2 learner production and processing of collocation: A multi-study perspective. The Canadian Modern Language Review, 64(3), 429-458.

Stake, R. 1995. The art of case study research. Thousand Oaks, Calofornia: Sage.

Sugiyono 2010. Metode penelitian kuantitatif, kualitatif dan R dan D. Bandung: Alfabeta.

Sung, J. 2003. English lexical collocations and their relation to spoken fluency of adult non-native speakers. Unpublished doctoral dissertation, Indiana University of Pensylvania, Pensylvania, USA.

Yan, H. 2010. Study on the causes and countermeasures of the lexical collocation mistakes in College English. English Language Teaching. March 2010: 162-165.

Yin, R. K. 1984. Case study research: Design and methods. Newbury Park, CA: Sage.

Zhang, X. 1993. English collocations and their effect on the writing of native and nonnative college freshmen. Indiana University of Pennsylvania: Pennsylvania.

Zughoul, M.R., \& Abdul-Fattah, H. 2003. Collocational strategies of Arab learners of English: A study in lexical semantics. (ERIC Document Reproduction Service No. ED 479746). 